\title{
Hydrobiology and Fisheries Laboratory, Alexandria
}

\begin{abstract}
T a review that appeared in NATURE ${ }^{1}$ of some 1 publications of the Directorate of Hydrobiology and Fisheries, Egypt, F. S. Russell concludes thus: "Now that research is on so sound a footing, the Egyptian Government should see grounds for fostering and furthering investigations in this most in. teresting region". Dr. C. Crossland has already described in NATURE ${ }^{2}$ the Marine Station of the Egyptian University at Hurghada on the Red Sea, and a short description of the Egyptian Government Laboratory on the Mediterranean at Alexandria may be of interest.
\end{abstract}

The favoured position of Egypt overlooking two seas, the incomplete knowledge we possess of the Eastern Mediterranean basin, and the existence of two main factors influencing that basin, namely, the opening of the Red Sea on the Mediterranean through the Suez Canal, and the Nile flood arriving at the coast by the end of summer, and throwing great quantities of freshwater into the Mediterranean-all these facts present problems of exceptional interest for research workers in aquatic biology.

The Cambridge Expedition to the Suez Canal ${ }^{3}$ has already proposed to repeat its exploration after a lapse of only ten years. Workers at the Hydrobiology and Fisheries Laboratory have carried out some research round Alexandria, in which the effect of the Nile flood on the area is incidentally touched upon. In the Suez Canal, the regime of currents has been studied by monthly observations of salinity, oxygen content and temperature at nine stations on the Canal ; and the movements of the phytoplankton have been examined at six stations. These studies must be continued in order to observe any changes produced by the Red Sea waters reaching the Mediterranean for at least nine months every year, and the Nile flood water breaking, between September and August, through the earth barrages artificially raised at the mouth of the delta every year in February.

The Laboratory at Alexandria offers facilities for visiting scientific workers to proceed with research on these lines, or in any other direction. A launch is attached to the Laboratory, for short coastal trips, and the research steamer Mabahiss can be used for more important cruising.

The laboratory is a three-storied building, situated on the tongue of land supposed to be the promontory of Pharos Island, on which stood the famous lighthouse of the Ptolemies. It overlooks, from the southeastern side, the bay now known as the Eastern Harbour, and from the north-western side, the open sea. This situation unites the advantages of being right near the sea, and of being twenty minutes journey by bus or tramway from the centre of the town of Alexandria. Accommodation for living on the premises of the laboratory is thus rendered unnecessary.

The ground floor contains the show-aquarium, with twenty-four tanks, and sea or fresh-water ad libitum. There are four research cubicles, with sea and fresh. water laid on to taps, and possibility of establishing research aquaria when needed. The chemical store, a dark-room, bath-room, lavatories, and store-room for gear, etc., complete the ground-floor. 